Univerzitet u Beogradu
Poljoprivredni fakultet
Institut za poljoprivrednu tehniku
Naučni časopis
POLJOPRIVREDNA TEHNIKA
Godina XLVI
Broj 2, 2021.
Strane: $28-37$

\title{
DEVELOPMENTS OF ORCHARD TILLERS AND THEIR ASSESSMENT OF INTERCULTURAL WORK QUALITY FOR SUITABLY IN TARAI REGION OF PANTNAGAR
}

\author{
Sharad Kumar Namdev ${ }^{* 1}$, Rajnarayan Pateriya ${ }^{2}$, Jagdish Manikrao ${ }^{3}$ \\ ${ }^{1}$ Farm Machinery and Power Engineering, Zila Parishad Krishi Mahavidhalaya Banda, \\ Bundelkhand University Jhansi, Uttar Pradesh, India \\ ${ }^{2}$ Farm Machinery and Power Engineering, College of Technology, Govind Ballabh Pant \\ University of Agriculture and Technology, Pantnagar, Uttarakhand, India \\ ${ }^{3}$ Agricultural Engineering, Centre of Scientific and Industrial Research, Central \\ Mechanical Engineering Research Institute, Centre of Excellence for Farm Machinery, \\ Ludhiana, Punjab, India
}

\begin{abstract}
Rotary tillers implements are now projected as important tillage machinery for better seedbed preparation; however the ordinary rotavator being in line with the tractor center line at the rear cannot be used in orchards due to the hindrance posed due to narrow space between the plants. Therefore, the concept of a rotary offset tiller in other words orchard tillers was proposed, which could perform finer intercultural operation between the plants. Since there are some models of Indians and Foreign made rotary offset tiller available and their work quality parameter significantly plays a crucial role in selection of efficient, effective and appropriate machine for orchards. Therefore, present study is carried out with a purpose of selection of suitable and efficient orchard tillers on the basis of intercultural work quality parameters. The various intercultural machines like Rineri offset tiller, Saktiman offset tiller and Side shift tiller selected for this study and finally, orchard tillers were analysed for intercultural work quality for their suitability in Pant Tarai region of Uttarakhand.
\end{abstract}

\footnotetext{
* Corresponding Author. E-mail: sharadsftr@gmail.com
} 
The work quality assessments concluded that side shift tiller was supposed to be best among all other type of intercultural machines because of less fuel consumption 3.5 $\mathrm{l} / \mathrm{h}$, less mean weight diameter $42 \mathrm{~mm}$, higher actual field capacity 0.47 and high field performance index $86 \%$. Therefore, side shift tiller can be recommended to farmers and found to be suitable for intercultural operation in Pant Tarai region.

Key words: Tillage, Rotary Offset Tiller, Intercultural Operations

\section{NEED OF ORCHARD TILLERS}

The lighter and finer operations carried out on the soil, between sowing had harvesting are termed as intercultural operations. They include weeding, fertilizer application, mulching, etc. The implements like rotary offset tiller, offset harrow, cultivators used for this purpose are called as intercultural equipment's. The rotavator (derived from rotary cultivator) is a tractor mounted active tillage implement comprising of blades mounted on flanges with affixed to a shaft that is driven by the tractor (PTO). Rotavator performs (one plowing and two harrowing) operation in single pass therefore, rotavator is accepted by the majority of farmers in Indian, as a time-saving equipment under low land and high land conditions. It gave higher quality of work (25-30\%) than the cultivator (Sahay et al. 2009). The degree of soil pulverization attained by the rotavator is more as compared to harrow and cultivator. The energy required per unit volume of soil for rotavator is about 39.2 to $47.0 \mathrm{MJ} / \mathrm{m}^{3}$ while, 70.7 to $116.3 \mathrm{MJ} / \mathrm{m}^{3}, 62.2$ to 103 $\mathrm{MJ} / \mathrm{m}^{3}$ and 53.3 to $110.2 \mathrm{MJ} / \mathrm{m}^{3}$ for mould board plough, desi plough and cultivator respectively (Salokhe et al. 2003). Rotary tillage implements are also one of most important versatile tillage machinery for better seedbed preparation but a simple rotavator cannot be used for intercultural operations due to obstruction imposed due to narrow space between the orchards. Therefore, rotary offset tiller came into existence, which performs effectively and finer intercultural operation (Namdev et al. 2017)

\section{DEVELOPMENTS OF ORCHARD TILLERS}

Orchard tillers are one of the most useful implement for performing intercultural operation. Initially, some popular foreign developed intercultural machines like Rineri made in Italy, Rotomec and Minos Agri made in USA, Howard made in Australia etc., were imported but after that some of progressive local agriculture firms in India like Shaktiman, FieldKing, etc. also started to manufacture orchard tillers. The orchard tillers like Renieri and Shaktiman were tested for work quality parameter evaluation under DST research project running with collaboration of CSIR, CMERI, COEFM, Ludhiana (Punjab) with various testing center of machinery located in various agricultural universities like PAU, Ludhiana (Punjab), GBPUAT, Pantnagar (Uttarakhand), JNKVV, Jabalpur (Madhya Pradesh) etc. but their work quality is not found satisfactory. Therefore, scientists of Center of Scientific and Industrial Research, Center of Excellence for Farm Machinery, Central Mechanical Engineering Research Institute, Ludhiana (Punjab) designed and developed a new orchard tiller which is also popular as side shift tiller and tested for work quality assessment by 
Department of Farm Machinery and Power Engineering, College of Technology, Govind Ballabh Pant University of Agriculture and Technology, Pantnagar (Uttarakhand).

The views of different orchard tillers are shown in Figure 1, Figure 2 and Figure 3 whereas their technical and brief specifications are tabulated in Table 1, Table 2, Table 3, Table 4 and Table 5.

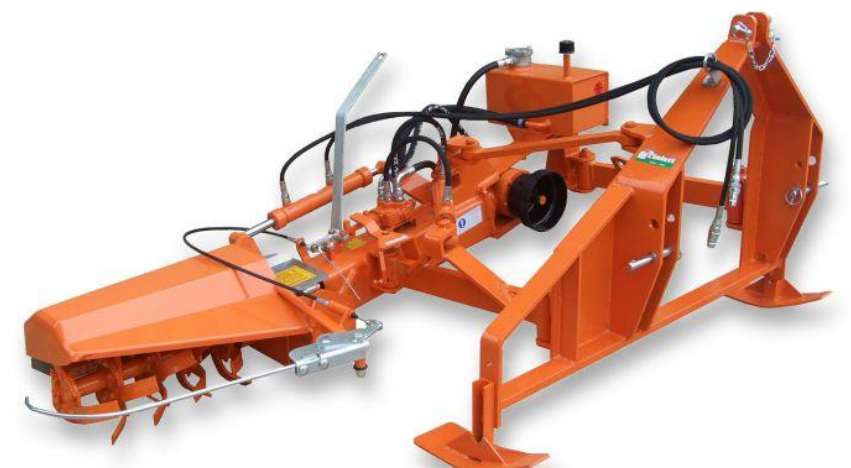

Fig. 1. Rinieri offset tiller

Table 1. Technical specifications of a Rinieri offset tiller (Pal, 2012.)

\begin{tabular}{|c|c|c|c|c|c|}
\hline Model & $\begin{array}{l}\text { Offset of the } \\
\text { machine }(\mathrm{m})\end{array}$ & $\begin{array}{l}\text { Working } \\
\text { width }(\mathrm{cm})\end{array}$ & Power (hp) & Weight, Kg & $\begin{array}{l}\text { Operating } \\
\text { Depth, }(\mathrm{m})\end{array}$ \\
\hline FS 100 & 0.40 & $55-70$ & $20+$ & 230 & 0.20 \\
\hline FS 130 & 0.40 & $55-70$ & $20+$ & 230 & 0.25 \\
\hline FS 160 & 0.50 & $55-70$ & $25+$ & 270 & 0.20 \\
\hline FS 200 & 0.50 & $55-70$ & $30+$ & 350 & 0.20 \\
\hline FS 220 & 0.50 & $70-85$ & $40+$ & 380 & 0.20 \\
\hline
\end{tabular}

Table 2. Brief specification of a Rinieri offset tiller (Pal, 2012.)

\begin{tabular}{|l|l|l|}
\hline $\begin{array}{l}\text { S.L. } \\
\text { No. }\end{array}$ & Specification & Units \\
\hline 1. & Power requirement & $30-50 \mathrm{hp}$ \\
\hline 2. & Number of flanges & 5 \\
\hline 3. & Spacing between flange plates & $550 \mathrm{~mm}$ \\
\hline 3. & Type of blades & L- Shape \\
\hline 4. & Number of blades & 30 \\
\hline 5. & Effective Working Width & $550-700 \mathrm{~mm}$ \\
\hline 6. & Working cut & $200 \mathrm{~mm}$ \\
\hline 7. & Minimum offset & $500 \mathrm{~mm}$ \\
\hline
\end{tabular}




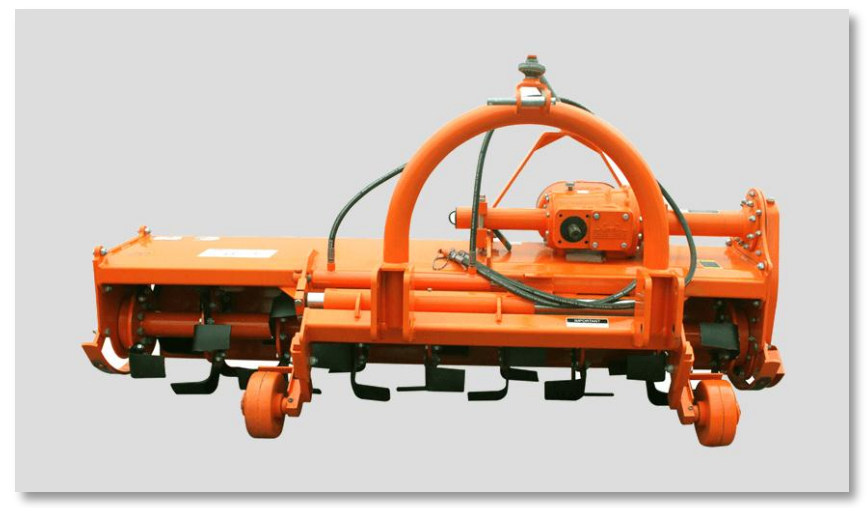

Fig. 2. Shaktiman offset tiller

Table 3. Technical specifications of aS offset tiller (Saktiman Manual, 2013.)

\begin{tabular}{|l|c|c|c|c|c|}
\hline \multicolumn{1}{|c|}{ Model } & $\begin{array}{l}\text { Offset of the } \\
\text { machine }(\mathrm{m})\end{array}$ & $\begin{array}{l}\text { Working } \\
\text { width }(\mathrm{cm})\end{array}$ & Power (hp) & Weight, Kg & $\begin{array}{l}\text { Operating } \\
\text { Depth, (m) }\end{array}$ \\
\hline SRT 4 & 0.9 & 116 & $34+$ & 419 & 0.20 \\
\hline SRT 5 & 1.2 & 150 & $40+$ & 460 & 0.25 \\
\hline SRT 5.5 & 1.3 & 163 & $50+$ & 470 & 0.20 \\
\hline SRT 6 & 1.4 & 178 & $55+$ & 479 & 0.20 \\
\hline VLS 135 & 1.0 & 135 & $40+$ & 500 & 0.12 \\
\hline VLS 150 & 1.0 & 155 & $45+$ & 530 & 0.12 \\
\hline
\end{tabular}

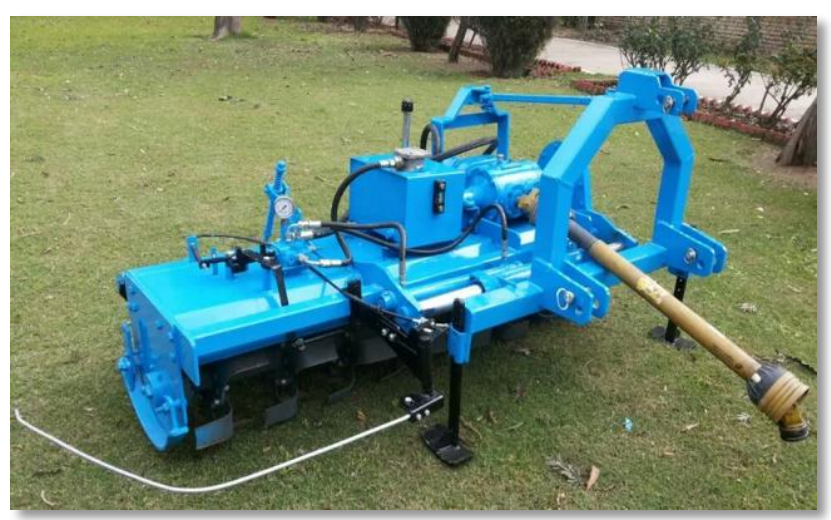

Fig. 3. Side shift tiller 
Table 4. Brief Specifications of a Shaktiman offset tiller (Saktiman Manual, 2013.)

\begin{tabular}{|c|l|l|}
\hline $\begin{array}{c}\text { S.L. } \\
\text { No. }\end{array}$ & Specification & Units \\
\hline 1. & Power requirement & $40 \mathrm{hp}$ \\
\hline 2. & Number of flanges & 5 \\
\hline 3. & Spacing between flange plates & $270 \mathrm{~mm}$ \\
\hline 4. & Type of blades & C-Shape \\
\hline 5. & Number of blades & 30 \\
\hline 6. & The overall height of rotary offset tiller & $1112 \mathrm{~mm}$ \\
\hline 7. & The overall width of rotary offset tiller & $1027 \mathrm{~mm}$ \\
\hline 8. & The overall length of rotary offset tiller & $1730 \mathrm{~mm}$ \\
\hline 9. & Effective working width & $1350 \mathrm{~mm}$ \\
\hline 10. & Maximum working depth & $400 \mathrm{~mm}$ \\
\hline 11. & Minimum offset & \\
\hline
\end{tabular}

\section{BRIEF DESCRIPTION OF MODIFIED SIDE SHIFT TILLER}

The rotary offset tiller has rotating tines mounted on a horizontal shaft and can be attached to the three point linkage of 50-65 hp tractors. It is powered by PTO and provided with adjustable mechanical sensing unit which can be adjusted at any position on the frame according to the type of orchard with a side shift of $300 \mathrm{~mm}$. It has seven flanges spaced $220 \mathrm{~mm}$ apart and each flange carries in it six blades. It is also provided with an external gear type pump of capacity $15 \mathrm{lit} / \mathrm{min}$ driven by PTO of the tractor. The modified side shift tiller is presented in Figure 3. 
Table 5. Brief specification of side shift tiller (Namdev, 2015.)

\begin{tabular}{|c|c|c|}
\hline S.L. No. & Specification & Units \\
\hline 1. & Power requirement & $50 \mathrm{hp}$ \\
\hline 2. & Number of flanges & 7 \\
\hline 3. & Type of blades & L- Shape \\
\hline 4. & Number of blades & 42 \\
\hline 5. & Flange plate diameter & $400 \mathrm{~mm}$ \\
\hline 6. & Rotor shaft diameter & $280 \mathrm{~mm}$ \\
\hline 7. & Spacing between flange plates & $235 \mathrm{~mm}$ \\
\hline 9. & The overall height of offset rotavator & $1120 \mathrm{~mm}$ \\
\hline 10. & The overall width of offset rotavator & $2000 \mathrm{~mm}$ \\
\hline 11. & The overall length of offset rotavator & $400 \mathrm{~mm}$ \\
\hline 12. & Rated width of cut & $1800 \mathrm{~mm}$ \\
\hline 13. & Hydraulic sift & $370 \mathrm{~mm}$ \\
\hline 14. & Standard position offset & $500 \mathrm{~mm}$ \\
\hline 15. & Right side maximum offset & $650 \mathrm{~mm}$ \\
\hline 16. & Left side minimum offset & $300 \mathrm{~mm}$ \\
\hline
\end{tabular}

\section{TECHNICAL MODIFICATIONS OF SIDE SHIFT ROTARY TILLER}

On the basis of work quality parameters of various orchard tillers and considering the problems of farmers at ground level as well as problems arising during intercultural operations in different orchards, the following modifications has introduced in side shift tiller designed and developed by Center of Scientific and Industrial Research, Central Mechanical Engineering Research Institute, Center of Excellence for Farm Machinery, Ludhiana (Punjab). 
1. The side shift system of the machine can be adjusted and fixed at any position with the help of retaining screw so it can be used both as ordinary rotary tiller as well as side shift tiller.

2. The working width of developed side shift tiller was increased from $0.40 \mathrm{~m}$ to $1.8 \mathrm{~m}$ hence covers larger area between orchards.

3. The sensing unit was adjustable and can be moved at any position on the frame according to type of orchards. It was also provided with adjusting sensing rod which can be settled at any angle ranges from $5^{0}$ to $7^{0}$ with the help of adjusting slotting plate fixed at any position.

\section{JUSTIFICATION OF MODIFICATIONS OF SIDE SHIFT TILLER}

(1.) Farmers can not offered normal rotary tiller and rotary offset tiller separately for different purposes Therefore, side shift system of the machine can be adjusted and fixed at any position with the help of retaining screw hence machine can be used both as ordinary rotary tiller as well as side shift tiller which causes farmers need not to purchase separate machinery for intercultural operation.

(2.) The both rotary offset tillers cover less area between orchards due to smaller effective working width. Therefore, side shift tiller working width is increased from 0.40 $\mathrm{m}$ to $1.8 \mathrm{~m}$, in which, it covers larger area between orchards within less time.

(3.) Side shift tiller is provided by adjusting sensing unit, in which, it can adjust at any position on the frame according to type of orchards. It is also provided with adjusting sensing rod which can be adjusted at any angle ranges from $5^{0}$ to $7^{0}$ with the help of adjusting slotting plate fixed at any position. Thus, side shift tiller can performs intercultural operation effectively in narrow space between orchards.

\section{INTERCULTURAL WORK QUALITY PARAMETERS OF DIFFERENT ORCHARD TILLERS}

Table 6. Work quality results of different orchard tillers

\begin{tabular}{|l|c|c|c|}
\hline \multirow{2}{*}{\multicolumn{1}{|c|}{ Parameters }} & \multicolumn{3}{|c|}{ Intercultural Operations } \\
\cline { 2 - 4 } & $\begin{array}{c}\text { Rineri } \\
\text { Offset Tiller }\end{array}$ & $\begin{array}{c}\text { Shaktiman } \\
\text { Offset Tiller }\end{array}$ & $\begin{array}{c}\text { Side } \\
\text { Shift Tiller }\end{array}$ \\
\hline Fuel Consumption, $1 / \mathrm{h}$ & 4.2 & 5.0 & 3.5 \\
\hline Mean Weight Diameter (MWD), mm & 58 & 45 & 42 \\
\hline Actual Field Capacity, ha/h & 0.35 & 0.45 & 0.47 \\
\hline Field Performance Index, $\%$ & 79 & 82 & 86 \\
\hline
\end{tabular}




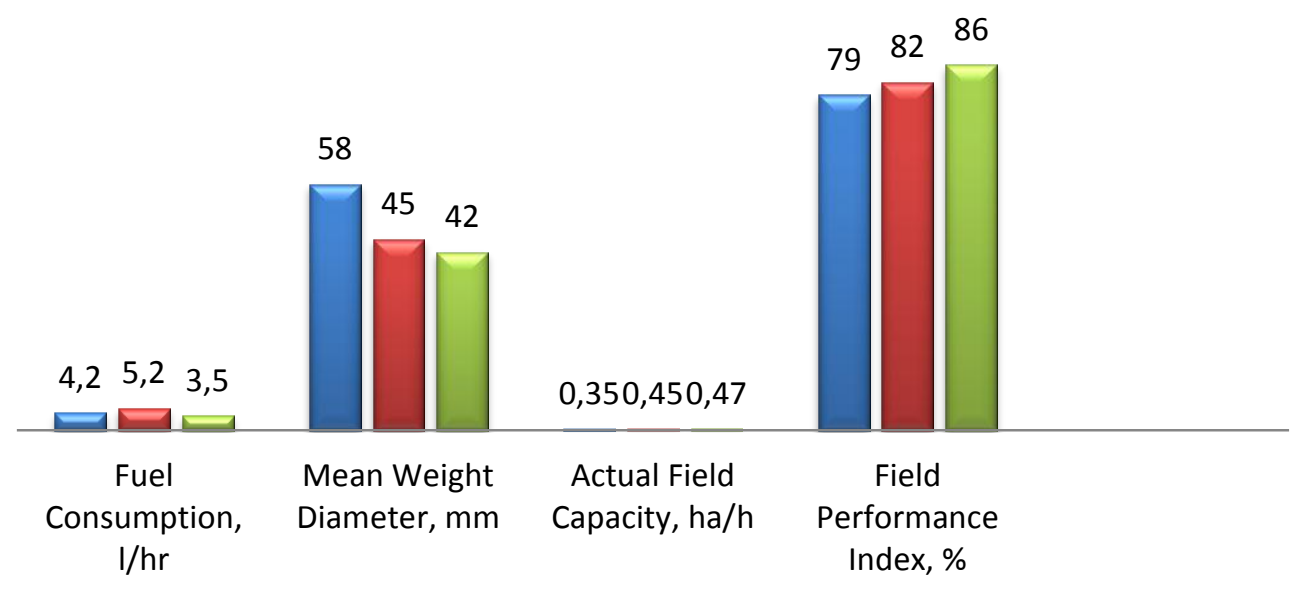

Fig. 4. Intercultural work quality of different orchard tillers

\section{CONCLUSION}

The results shows that use of side shift tiller reduced the number of operations thereby increasing the overall field capacity and field performance index along with reducing time required for intercultural operation. The work quality obtained was supposed to be superior as compare to other orchard tillers and it was also possible to incorporate all stubble and residues into soil. Thus, side shift tiller can be recommended for Pantnagar Tarai region farmers for intercultural operation.

\section{ACKNOWLEDGEMENTS}

The authors are thankful to Center of Scientific and Industrial Research, Central Mechanical Engineering Research Institute, Center of Excellence for Farm Machinery, Ludhiana (Punjab) for developing side shift tiller and special thanks also goes to Govind Ballabh Pant University of Agriculture and Technology, Pantnagar, (Uttarakhand) for providing research oriented resources. Authors are also taken consideration of many valuable research studies carried out by other researchers which make present short communication paper very significant. Finally, Authors are also grateful to reviewers team for his valuable comments and suggestions to improve the quality of short communication paper. 


\title{
REFERENCES
}

[1] Anonymous. 2013. Shaktiman. Tirth agro pvt limited, Technical Specification manual on various models of rotary offset tiller.

[2] Namdev, S. K. 2015. Performance Evaluation of an offset rotavator. Unpublished M. Tech. Thesis, Govind Ballabh Pant University of Agric. and Technology, Pantnagar, Uttarakhand, India. [3] Pal, R. 2012. Performance Evaluation of an offset rotavator for different type of orchards. Unpublished M. Tech. Thesis, Govind Ballabh Pant University of Agriculture and Technology, Pantnagar, Uttarakhand, India.

[4] Salokhe, V. M. and Ramalingam, N. 2003. Effect of rotation direction of a rotary tiller on draft and power requirements in a Bangkok clay soil. Journal of Terramechanics, 39(5): 195-205.

[5] Sahay, C.S., Thomas, E. V. and Satapathy, K. K. 2009. Performance evaluation of a novel power-tiller-operated oscillatory tillage implement for dry land tillage. Bio Systems Engineering, 102(42): 385-391.

[6] Namdev, S. K., Pateriya, R. N. 2017. Performance evaluation of a modified offset rotavator in mango orchard. Agricultural Engineering, Year XLII, No. 2: 25-34.

[7] Sharda, A. and Singh, S. 2004. Effect of selected parameters on field performance of rotary tiller. IE (I) Journal of agricultural engineering, 85(1): 22-25.

\section{RAZVOJ ROTACIONIH ALATA I PROCENA KVALITETA NJIHOVOG INTERAKTIVNOG RADA POGODNOG ZA VOĆNJAKE TARAI I PANTNAGAR REGION (Indija)}

\author{
Sharad Kumar Namdev ${ }^{* 1}$, Rajnarayan Pateriya ${ }^{2}$, Jagdish Manikrao ${ }^{3}$ \\ ${ }^{I}$ Farm Machinery and Power Engineering, Zila Parishad Krishi Mahavidhalaya Banda, \\ Bundelkhand University Jhansi, Uttar Pradesh, India \\ ${ }^{2}$ Farm Machinery and Power Engineering, College of Technology, Govind Ballabh Pant \\ University of Agriculture and Technology, Pantnagar, Uttarakhand, India \\ ${ }^{3}$ Agricultural Engineering, Centre of Scientific and Industrial Research, Central \\ Mechanical Engineering Research Institute, Centre of Excellence for Farm Machinery, \\ Ludhiana, Punjab, India
}

Sažetak: Oprema (alati) za rotacione freze danas se predviđa kao važna za obradu zemljišta i bolju pripremu međuprostora u voćnjacima. Međutim, obične mašine sa rotacionim alatima koji se nalaze u ravni sa srednjom linijom vuče i sa zadnje strane traktora, ne mogu se uspešno koristiti u voćnjacima zbog smetnji u uskom (ograničenom) prostoru između biljaka.

Zato je predložen u ovom radu, koncept rotacione freze, koji bi mogao da izvrši finiju obradu prostora između redova u voćnjaku.

\footnotetext{
${ }^{*}$ Corresponding Author. E-mail: sharadsftr@gmail.com
} 
Budući da su na raspolaganju neki modeli rotacionih alata (freza) sa proizvodnjom u Indiji i inostranstvu, njihovi parametari kvaliteta rada igraju presudnu ulogu u odabiru efikasne, efikasne i odgovarajuće mašine za voćnjake u Indiji . Zato se ovo istraživanje sprovodi u svrhu izbora pogodnih i efikasnih rotofreza za voćnjake na osnovu parametara kvaliteta interaktivnog rada.

Različite mašine za rad međurednom prostoru u voćnjacima, kao što je Rineri, Saktiman i Side rotofreza su odabrane za ovu studiju, i na kraju, analizirane na kvalitet interaktvnih parametara rada kako bi se primenile u regionu Pant Tarai u Uttarakhandu (Indija).

Procene kvaliteta rada omogućuju zaključak: rotofreza sa bočnim pomeranjem alata treba biti najbolja među svim ostalim vrstama interativnih mašina zbog manje potrošnje goriva 3,5 l/h, manjeg srednjeg prečnika alata od $42 \mathrm{~mm}$, većeg stvarnog učinka od 0,47 ha/h i visokog indeksa performansi mašine u radu od $86 \%$.

Zato se farmerima može preporučiti konstrukcija mašine rotofreze (Side Shift Tiller) sa bočnim pomeranjem alata, koja se može pogodno primeniti za interaktivne operacije u voćnjacima u regionu Pant Tarai (Indija).

Ključne reči: obrada zemljišta, rotaciona freza, interaktivne operacije

Prijavljen:

Submitted: 25.01.2021.

Ispravljen:

Revised: 18.04 .2021$.

Prihvaćen:

Accepted: 10.05.2021. 